\title{
Performance Enhancement and Immunity Profile of Broiler Treated Feed Additive Containing Lactic Acid Bacteria and Ganoderma lucidum
}

\author{
A. Sofyan ${ }^{\mathrm{a}, *}$, M. Angwar ${ }^{\mathrm{a}}$, H. Herdiann ${ }^{\mathrm{a}}$, E. Damayanti ${ }^{\mathrm{a}}$, L. Istiqomah ${ }^{\mathrm{a}}$, A. Febrisiantosa ${ }^{\mathrm{a}}$,H. Julendra ${ }^{\mathrm{a}}$, \\ M. H. Wibowo ${ }^{\text {, \& T. Tntari }}{ }^{\mathrm{b}}$ \\ aDivision of Animal Feed \& Nutrition, Center for Chemical Processes Development \& Engineering (UPT. BPPTK), \\ Indonesian Institute of Sciences (LIPI) \\ Jln. Yogya-Wonosari Km. 31.5, Gading, Playen, Gunungkidul, D. I. Yogyakarta 55861, Indonesia \\ ${ }^{b}$ Laboratory of Microbiology, Faculty of Veterinary Medicine, Gadjah Mada University (UGM), \\ Yogyakarta 55281, Indonesia \\ (Received 01-10-2012; Reviewed 24-11-2012; Accepted 28-12-2012)
}

\begin{abstract}
The experiment was conducted to evaluate the influence of feed additive containing lactic acid bacteria (LAB) and Ganoderma lucidum (GL) on body weight gain (BWG), feed efficiency (FE), performance index (PI), antibody titer (AT) against Newcastle disease and histopathology of broilers. Bacteria used were Lactobacillus salivarius and Pediococcus pentosaceus, which were isolated from broiler's intestine. A number of 195 unsexed day old chicks (Cobb strain) were arranged in a completely randomized design and consisted of 5 treatments, each in 3 equal replicates. The treatments were as followed T0: control/without-feed additive, T1: 1\% LAB (10 $\left.\mathrm{cfu}^{-1}\right)$, T2: 1\% GL, T3: 1\% of LAB $10^{9} \mathrm{cfu} \mathrm{g}^{-1}+$ GL (1:1), T4: commercial antibiotic. Data were analyzed using ANOVA and continued to Duncan's multiple range test. The results showed that T2, T3, T4 treatments significantly improved $(\mathrm{P}<0.05)$ BWG, FE and PI of broilers. Broilers fed T3 had the highest PI, followed by T4, T1, T2 and T0. Broilers fed T3 had the highest AT value followed by T0, T2, T4, and T1. Histopathology profile showed that broiler fed $\mathrm{T} 3 \mathrm{~h}$ had no lesion on liver and intestine compared to others. The result of this experiment indicated that additive containing $0.25 \%$ L. salivarius, $0.25 \% P$. pentosaceus, and $0.5 \%$ G. lucidum was able to enhance broiler performance.
\end{abstract}

Key words: broilers, G. lucidum, Immunity, L. salivarius, P. pentosaceus

\section{ABSTRAK}

Penelitian ini bertujuan untuk mengevaluasi pengaruh aditif pakan yang mengandung bakteri asam laktat (BAL) dan Ganoderma lucidum (GL) terhadap pertambahan berat badan (PBB), efisiensi pakan (EP), indeks performa (IP), titer antibodi (TA) terhadap Newcastle disease dan gambaran histopatologi ayam broiler. Bakteri yang digunakan adalah Lactobacillus salivarius dan Pediococcus pentosaceus, yang diisolasi dari usus ayam. Sebanyak 195 ayam broiler umur sehari (unsexed) strain $C o b b$ dibagi secara acak ke dalam 5 perlakuan dan 3 ulangan dalam rancangan acak lengkap. Perlakuan yang diberikan terdiri atas T0: kontrol negatif (tanpa aditif pakan), T1: BAL $1 \%$ ( $10^{9} \mathrm{cfu}$ $\mathrm{g}^{-1}$ ), T2: 1\% GL, T3: campuran 1\% dari BAL $10^{9} \mathrm{cfu} \mathrm{g}^{-1}+\mathrm{GL}$ (1:1), T4: antibiotik komersial. Data yang didapatkan dianalisis dengan ANOVA dan dilanjutkan dengan uji jarak berganda Duncan. Hasil penelitian menunjukkan bahwa ayam dengan perlakuan T2, T3, T4 meningkat secara signifikan $(\mathrm{P}<0,05)$ pada parameter PBB, EP dan IP. Ayam broiler yang mendapatkan perlakuan T3 memiliki nilai IP tertinggi, diikuti oleh T4, T1, T2, dan T0. Peningkatan nilai TA tertinggi pada ayam yang mendapat T3 diikuti oleh T0, T2, T4, dan T1. Berdasarkan gambaran histopatologi organ hati dan usus ayam yang diberi T3 bahwa tidak terdapat lesi organ hati dan usus halus dibandingkan perlakuan lainnya. Hasil dari penelitian ini menunjukkan bahwa pemberian aditif pakan yang mengandung $0,25 \%$ L. salivarius, $0,25 \%$ P. pentosaceus dan $0,50 \%$ G. lucidum mampu meningkatkan performa ayam broiler.

Kata kunci: ayam broiler, G. lucidum, Imunitas, L. salivarius, P. pentosaceus

*Corresponding author:

Phone: +62-274-392570; E-mail: sofyan_lipi@yahoo.co.id 


\section{INTRODUCTION}

Since the used of dietary antibiotic in promoting the poultry growth had been banned by the European Union in 1999 (Casewell et al., 2003), some researchers concern to explore alternative substances to replace antibiotic. Antibiotic growth promoters (AGPs) were used to prevent pathogen and poultry disease, however it have many disadvantages, one of which is resistance to pathogenic bacteria as well as it residue in poultry product (Khaksefidi \& Rahimi, 2005; Hume et al., 2011).

Either probiotic, prebiotic or active compound from natural sources were widely used for replacing AGPs. Food and Agriculture Organization (FAO)-World Health Organization (WHO) defined probiotic as live microorganisms when administered in adequate amounts and confer a health benefit on the host (Gagia et al., 2010). In addition, prebiotic is non-digestible substances that provide a beneficial physiological effect on the host by selectively stimulating the favorable growth or activity of a limited number of indigenous bacteria (Sekhon \& Jairath, 2010). Therefore, synbiotic was termed when a product contains both probiotics and prebiotic and it could be used to optimize broiler health status (Alavi et al., 2012).

Several attempts were conducted to find non-antibiotic feed additive ingredients such as probiotics from lactic acid bacteria, prebiotic from mannan oligosaccharide (MOS) or a combination thereof in the form synbiotic as additive for enhancing poultry health and productivity (Ashayerizadeh et al., 2011). Supplementation of prebiotic (MOS) had potency to improve immunity against Newcastle disease virus (Mehdi \& Hasan, 2012). The use of probiotics were able to reduce colonization of pathogenic bacteria in the intestine and reduced pathogenic bacteria (coliforms and campylobacter) contamination on the carcass (Khaksefidi \& Rahimi, 2005), and prevented diarrhea caused by Enteropathogenic Escherichia coli (EPEC) infection in male rats (Astawan et al., 2011).

Another alternative was the supplementation of G. lucidum mushroom on diet. Biomass of G. lucidum was known to have an ability to enhance the immune system. Polysaccharide in G. lucidum had been proven to increase the proliferation of T-lymphocytes and Blymphocytes which were implicated in the immunity system enhancement (Lin, 2005). Ogbe et al. (2008) had also reported that the addition of G. lucidum mushroom powder of 0.5 to $2 \mathrm{~g} / \mathrm{kg}$ in the feed increased immunity of laying hens.

The recent study, many researchers conducted evaluation of probiotic and prebiotic combination (synbiotic) on poultry. Jung et al. (2008) had reported that the use of Bifidobacteria lactis (probiotics) combined with specific substrate for growth (e.g. galacto oligosaccharide) favored intestinal growth and fecal microflora of broilers. In addition, Awad et al. (2009) studied effectivity of synbiotic consisting probiotic strain E. faecium, prebiotic derived from chicory, and immune-modulating substances was derived from sea algae affected the broiler performance and gut health. However, scientific report of synbiotic consisting LAB and G. lucidum effect on broiler performance and immunity is still limited.

The combination of probiotic from lactic acid bacteria and G. lucidum mushroom was expected to provide synergistic effects to enhance broiler performance and immunity leading to productivity improvement.

\section{MATERIALS AND METHODS}

\section{Research Stages}

The research consisted of formulation of feed additive, treatments of feed additive on broilers, antibody and histopathology analysis. Formulation and feeding trials had been conducted at Feed and Animal Nutrition Laboratory, Center for Chemical Processes Development and Engineering (UPT. BPPTK), Indonesian Institute of Sciences (LIPI), Yogyakarta. Probiotic was prepared by freeze-drying technique in Research Center for Biotechnology, LIPI, Cibinong, Bogor. Histopathology sample was prepared at Pathology Laboratory and antibody titer was analyzed at Laboratory of Microbiology, Faculty of Veterinary Medicine, Gadjah Mada University (UGM), Yogyakarta.

\section{Animal and Feed}

Day old chicks (Cobb strain) taken from commercial hatchery. Basal feed was produced by commercial feed mill. The feedstuff consisted of yellow corn, soybean meal, meat bone meal, corn gluten meal, palm oil and premix. Nutrient composition of basal diet based on packaging and proximate analysis showed on Table 1.

\section{Feed Additive}

Treatments of feed additive consisted of probiotic from lactic acid bacteria of L. salivarius and P. pentosaceus isolated from broilers intestines and provided in powder form was prepared by freeze-drying. Probiotic powder was containing $10^{9} \mathrm{cfu} / \mathrm{g}$ in equal proportion of L. salivarius and P. pentosaceus (1:1). Then, G. lucidum powder was prepared by oven dried at $55^{\circ} \mathrm{C}$ for $12 \mathrm{~h}$ and fol-

Table 1. Nutrients composition (as fed basis) of basal diet was produced by commercial feed mill (\%)

\begin{tabular}{lcc}
\hline Nutrients & $\mathrm{A}$ & $\mathrm{B}$ \\
\hline Moisture & 12.00 & 9.90 \\
Crude protein & 21.00 & 21.43 \\
Crude fiber & 9.57 & 4.69 \\
Ether extract & 5.00 & 5.61 \\
Nitrogen free extract & 53.98 & 53.30 \\
Ash & 7.00 & 5.07 \\
Calcium & 1.00 & 1.06 \\
Total phosphorus & 0.70 & $-*$ \\
\hline
\end{tabular}

Note: Basal diet had no contained antibiotic, A (based on nutrition fact was founded on packaging), B (based on proximate analysis result), -* no data. 
lowed by grinded and sheaved in 40 mesh particle size. Commercial antibiotic contained erythromycin $(2.5 \%)$ and chlortetracycline- $\mathrm{HCl}(13.5 \%)$ which was purchased from poultry shop.

\section{Feeding Trials}

An experiment to evaluate effect of feed additive on broilers was arranged by Completely Randomized Design. Feeding trials consisted of 5 treatments T0: negative control (without feed additive), T1: 1\% lactic acid bacteria (LAB) $\left(10^{9} \mathrm{cfu} \mathrm{g}^{-1}\right), \mathrm{T} 2: 1 \%$ of $\mathrm{G}$. lucidum (GL), T3: $1 \%$ of mixture of LAB $10^{9} \mathbf{c f u ~}^{-1}$ and GL (1:1), and T4: commercial antibiotic as positive control. Each treatment was set in 3 equal replicates and 13 broilers on each replication. Antibiotic treatment (T4) given to broiler as follow recommendation.

A number of 195 unsexed day old chicks (Cobb strain) were used and birds were weighed individu-

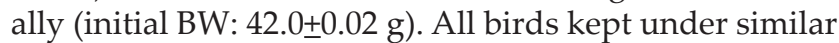
condition of management throughout the experimental period, which lasted for $35 \mathrm{~d}$ of age and free access to feed and drinking water. Initial brooding temperature was $33^{\circ} \mathrm{C}$ in the first week of age and reduced gradually $2{ }^{\circ} \mathrm{C}$ per wk and reached $24{ }^{\circ} \mathrm{C}$ at the end of experimental period. Feed additive treatments on broilers was started at second wk ( $7 \mathrm{~d}$ old $)$ of the experimental period, and only given once each seven days since 7 up to $21 \mathrm{~d}$ old. Broilers was treated feed additive (T1, T2, and T3) on feed as followed the dosage treatment. However, treatment of commercial antibiotic treated to broilers at $2 \mathrm{~g}$ per L drinking water.

Vaccinations administered to broilers at three times: firstly, Newcastle-ND vaccine Lasota at $3 \mathrm{~d}$ old, secondly IBD vaccine at $10 \mathrm{~d}$ old (intra nasal), and finally Newcastle disease vaccine at $18 \mathrm{~d}$ old (oral in drinking water). Performance data were recorded weekly from all of broilers. Index value of performance was calculated refers to Timmerman et al. (2006) using the equation as followed:

Production index $=$

[BWG x (100 - \%mortality] / [FCR x $100 \times$ period]

At the end of experimental period, six birds were chosen from each treatments group based on body weights mean, then slaughtered for histopathological evaluation of liver and intestine.

\section{Titer Antibody and Histopathology Analysis}

Blood serum was sampled for analyzing antibody titer against NDV (Newcastle Disease Virus), it was collected through the vein of brachialis at one and two weeks post vaccination respectively. Antibody titer was measured by the haemaglutination inhibition methods according to Rezaeianzadeh et al. (2011).

Liver and intestine samples were taken from each treatment and preserved immediately on $10 \%$ formalin solution. Prior to take profile of histopathology, sample had been prepared by staining with hemotoxcylinseosin (Gamble, 2008). Histopathological profiles were evaluated based observation of lesion at a targeted organ.

\section{Data Analysis}

The body weight (BW), body weight gain (BWG), feed intake (FI), feed conversion ratio (FCR), mortality, productivity index (PI), and antibody titer (AT) were compared between treatments by the analysis of variance (ANOVA) and subsequent Duncan Multiple Range Test (Gomez \& Gomez, 2007). Before statistical analysis, data from antibody titer were converted into logarithmic transformation ( $\log 2)$. Probability values of less than $0.05(\mathrm{P}<0.05)$ were considered significant difference. However, data from histopathology of liver and small intestine were evaluated descriptively.

\section{RESULTS AND DISCUSSION}

\section{Broiler Performance}

Body weight (BW), body weight gain (BWG), feed intake (FI), feed conversion ratio (FCR) and performance index (PI) in broilers fed feed additive treatments shown in Table 2. Broiler performance was significantly $(\mathrm{P}<0.05)$ influenced by feed additives containing lactic acid bacteria (LAB) and G. lucidum (GL). BW and BWG of broilers received either treatment of combination $\mathrm{LAB}$ + GL (T3) or commercial antibiotic (T4) were higher than control (T0), LAB (T1) and GL (T2).

Table 2. Performance and productivity index of broilers fed by feed additive treatments

\begin{tabular}{lrrrrr}
\hline \multicolumn{1}{c}{ Variables } & T0 (control) & \multicolumn{1}{c}{ T1 (LAB) } & \multicolumn{1}{c}{ T2 (GL) } & T3 (LAB + GL) & T4 (Antibiotic) \\
\hline BW (g/bird) & $1825.60 \pm 64.10^{\mathrm{c}}$ & $1892.30 \pm 53.30^{\mathrm{bc}}$ & $1930.30 \pm 51.00^{\mathrm{ab}}$ & $2002.60 \pm 16.00^{\mathrm{a}}$ & $1953.90 \pm 55.50^{\mathrm{ab}}$ \\
BWG (g/bird) & $1784.60 \pm 64.10^{\mathrm{c}}$ & $1851.30 \pm 53.30^{\mathrm{bc}}$ & $1889.30 \pm 51.00^{\mathrm{ab}}$ & $1961.60 \pm 16.00^{\mathrm{a}}$ & $1912.90 \pm 55.50^{\mathrm{ab}}$ \\
FI (g/bird) & $2788.10 \pm 84.10^{\mathrm{b}}$ & $2855.00 \pm 122.20^{\mathrm{ab}}$ & $2942.40 \pm 11.10^{\mathrm{a}}$ & $2958.60 \pm 58.80^{\mathrm{a}}$ & $2980.40 \pm 84.40^{\mathrm{a}}$ \\
FCR & $1.53 \pm 0.06^{\mathrm{a}}$ & $1.51 \pm 0.08^{\mathrm{a}}$ & $1.53 \pm 0.05^{\mathrm{a}}$ & $1.48 \pm 0.04^{\mathrm{a}}$ & $1.53 \pm 0.01^{\mathrm{a}}$ \\
Mortality (\%) & $0.00 \pm 0.00^{\mathrm{a}}$ & $0.00 \pm 0.00^{\mathrm{a}}$ & $2.60 \pm 4.40^{\mathrm{a}}$ & $0.00 \pm 0.00^{\mathrm{a}}$ & $0.00 \pm 0.00^{\mathrm{a}}$ \\
PI & $334.20 \pm 22.60^{\mathrm{a}}$ & $351.30 \pm 27.40^{\mathrm{a}}$ & $345.70 \pm 33.30^{\mathrm{a}}$ & $379.50 \pm 12.60^{\mathrm{a}}$ & $358.30 \pm 10.60^{\mathrm{a}}$ \\
\hline
\end{tabular}

Note: Means with different superscript differ significantly $(\mathrm{P}<0.05)$. LAB: lactic acid bacteria, GL: G. lucidum, BW: body weight, BWG: body weight gain, FI: Feed Intake, FCR: feed conversion ratio, PI: performance index. 
Percentage of mortality was not influenced by treatments. All treatments had zero mortality except for T2. Broiler fed by T2 had $2.6 \%$ of mortality. Furthermore, treatments had no effect on feed conversion ratio, however, broiler received by $\mathrm{T} 3$ treatment had tendency more efficient than other treatments. Based on BW, BWG, FCR and mortality, it can be calculated that the highest production index was obtained from broiler group received $\mathrm{T} 3$ treatment.

BW and BWG of broilers received either T2 and T3 or T4 had significantly increased compared to T0 and T1. It also related to the other parameters such as the FCR of broilers, which received feed additive tended to show a better result than control. Both of LAB and GL had positive effect on broiler performance. Moreover, their combination as feed additive enhanced broiler performance than single form as well as similarity with the antibiotic control. This was due to the synergistic effect of both ingredients. LAB produced some acids that decreased the $\mathrm{pH}$ levels in the digestive tract. The decreased of $\mathrm{pH}$ was very effective in controlling bacteria populations and increased levels of lymphocytes (Mehdi \& Hasan, 2012). Synergism between LAB + GL (T3) affected the optimized absorption of nutrients in the gastrointestinal tract that produced feed conversion ratio was better in synbiotic than other treatments. Results of previous studies by Khaksefidi \& Rahimi (2005) showed that the supplementation of $100 \mathrm{mg}$ six strains of lactic acid bacteria (Lactobacillus acidophilus, L. casei, Bifidobacterium bifidum, Aspergillus oryzae, Streptococcus faecium and Torulopsis sp.) in $1 \mathrm{~kg}$ of feed improved the performance and feed efficiency of broiler.

LAB cultures consisting $P$. pentosaceus and $L$. salivarius attempted to broilers as probiotic had mutual effect on nutrient digestion. The similar result was reported dietary supplementation of LAB ( $L$. reuteri $\operatorname{Pg} 4$ ) as probiotic improved significantly feed conversion of broiler compared with the control group (Yu et al., 2007). In addition, Mountzouris et al. (2007) studied that efficacy of probiotic containing Lactobacillus, Bifidobacterium, Enterococcus, and Pediococcus had capability in promoting broiler performance and modulating cecal microflora composition and metabolic activities. Those results showed that probiotic treatment was not only improving BWG and FCR but also to extent the activities of the cecal microflora.

Ashayerizadeh et al. (2009) also reported that the synbiotic primalc-MB-biolex able to increase body weight of 2,145.4 $\mathrm{g}$ compared to supplementation of antibiotics (Flavomycin), probiotics (Biolex-MB)and prebiotics (Primalac) $(\mathrm{P}<0.05)$. The feed conversion $(\mathrm{FCR})$ on synbiotic supplementation was better (2.08) than FCR on antibiotics, prebiotic, and probiotics supplementation. It means that the probiotic, prebiotic and synbiotic supplementation proven effective in improving feed conversion ratio $(\mathrm{P}<0.05)$ but did not affect feed intake $(\mathrm{P}>0.05)$.

Based on the Table 2, broilers consumed diet containing GL powder (T2) tend to higher BWG and feed efficiency than control /T0 and T1. Supplementation of GL in broilers diet had a positive effect on nutrient digestion. Application of G. lucidum in feed processing could improve feed quality. Misra et al. (2007) studied that mustard straw quality could increase through the solid-state fermentation using G. lucidum. Furthermore, G. lucidum had antimicrobial activity against pathogenic species of bacteria such as Escherichia coli, Staphylococcus aureus, Klebsiella pneumoniae, Bacillus subtilis, Salmonella typhi and Pseudomonas aeruginosa (Quereshi et al., 2010). G. lucidum extract had also contributed to support immunity by indication increasing lymphocytes and macrophages in chicken (Lee et al., 2010).

Performance of broiler treated by combination between probiotic and G. lucidum showed the highest performance index. This parameter related to the BWG, FCR and mortality that were improve by received T3 treatment (LAB + GL). Timmerman et al. (2006) conducted the field trial administered probiotic Lactobacillus to broiler resulted in a slight increase (by 1.84\%) in broiler productivity index.

\section{Profile of Broiler Immunity and Histopathology}

Broiler immunity was evaluated by antibody titters (AT) parameter. Prior to vaccination, broilers had AT mean value around 3 up to $4 \log 2$ and overall treatments showed increasing AT value after broilers treated by ND (Newcastle Disease) vaccine. However, broilers received T3 treatments seem to had higher immunities than others. Increasing of AT value indicated that broilers received $\mathrm{T} 3$ treatment had the highest immune response. The highest immunities status after vaccination was obtained in T3 treatment followed by T0, T2, T4, and T1 (Figure 1).

Effectivity of G. lucidum on immunity had been reported by Lin (2005) that polysaccharides of G. lucidum promoted humoral and cellular immunity. Mehdi \& Hasan (2012) had also stated that prebiotic consisting mannan oligosaccharide improving immunity (titer antibody) through the mechanism defense cells in the gutassociated lymphoid tissue (GALT). Probiotics modulate the host's immune system, affect other microorganisms directly or act on microbial products, host products or food components (Sekhon \& Jairath, 2010). An et al. (2008) reported that supplementation of prebiotic $(0.1 \%$ $\beta$-glucan) or probiotic $(0.2 \%$ Bacillus amyloliquefaciens

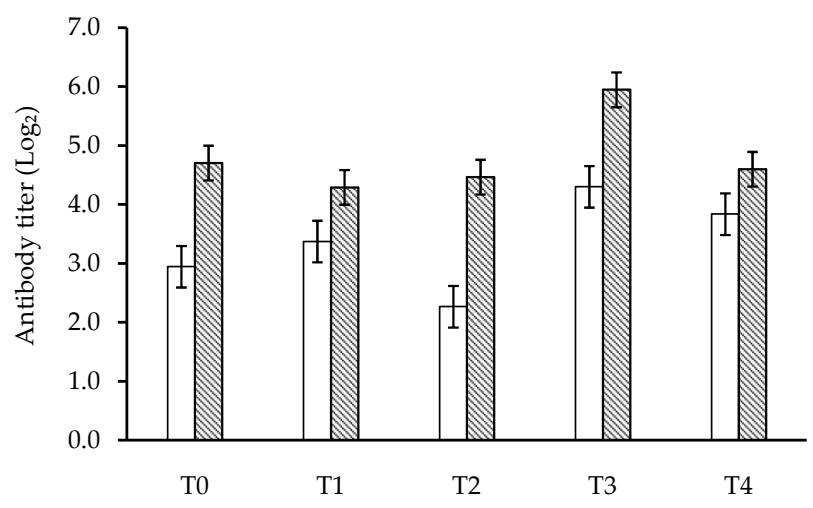

Figure 1. Titer antibody of broilers at one ( $\square)$ - two ( $\square)$ week after ND vaccination.. T0: control, T1: $1 \% \mathrm{LAB}, \mathrm{T} 2: 1 \%$ GL, T3: 1\% LAB+GL, T4: antibiotic. 
$\mathrm{T} 0$

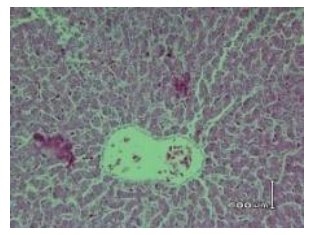

No specific pathological change

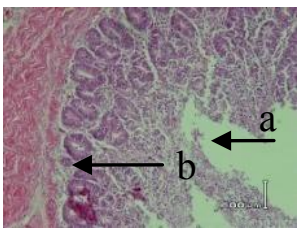

Epithelia erosion (a) \& lymphocyte infiltration (b)
$\mathrm{T} 1$

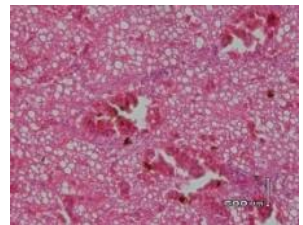

No specific pathological change

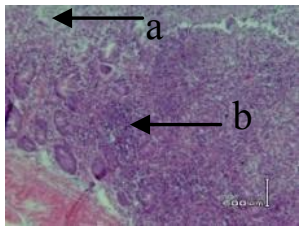

Epithelia erosion (a) \& lymphocyte infiltration (b)
$\mathrm{T} 2$

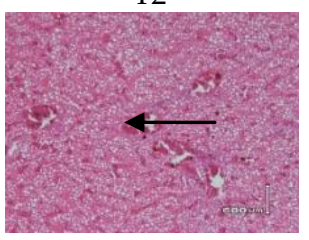

Weakened

degeneration

Liver

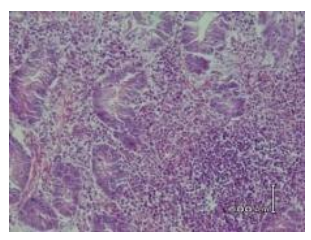

No pathological change

Intestine
T3

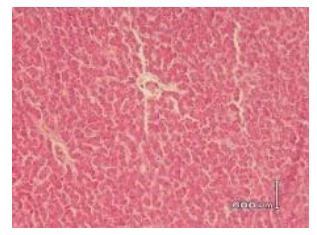

No specific

pathological change

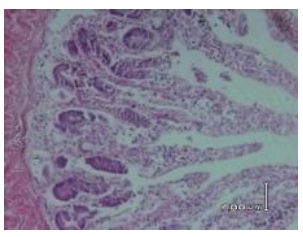

No pathological change
$\mathrm{T} 4$

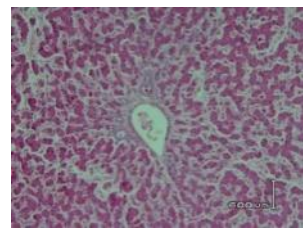

No specific pathological change

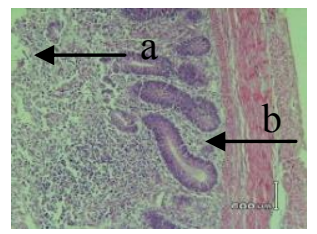

Epithelia erosion (a) \& lymphocyte infiltration (b)

Figure 2. Histopathology profile (M: 400X) of broiler internal organ (liver and intestine) fed by feed additive. T0: control, T1: $1 \%$ LAB, T2: 1\% GL, T3: $1 \%$ LAB + GL, T4: antibiotic.

KU801) significantly increase the antibody titer against Infectious Bursal Diseases Virus (IBV). Moreover, combination of probiotic and G. lucidum more improves broiler immunity than single form that indicated association effectivity. The role positively relationship between probiotic and probiotic had been reviewed by Gaggia et al. (2010) had a promising more capable to reduce the risk of intestinal diseases and remove specific microbial disorders than in single form.

Response of broiler immunity received feed additive treatment, which higher than control had correlation with the histopathology profile. Almost all treatments showed infiltration in intestine except for T2 and T3 treatment. However, broiler treated by T3 had no degeneration in liver compared to T2 (Figure 2). In the previous study, supplementation of natural additive from Lumbricus rubellus tends to decrease lesion of intestine and liver of broilers infected by Salmonella pullorum (Sofyan et al., 2010). Furthermore, Kalorey et al. (2005) reported that impaired immune response and histopathological changes in liver, thymus and other internal organ of broilers given mycotoxins were protected by supplementation of polyherbal additive.

Effectivity of feed additive consisted of prebiotic in combined with probiotic resulted in supporting immune system, consequently in improving broiler performance. This result suggested that supplementation prebiotic from yeast-derived $\beta$-glucan or probiotics B. amyloliquefaciens (An et al., 2008) and synbiotic consisted of prebiotic from poly/oligosaccharides and probiotic from lactic acid bacteria (Jung et al., 2008; Alavi et al., 2012) enhance growth performance and humoral immunity of broiler chicks.

\section{CONCLUSION}

Supplementation of feed additive consisted of $0.5 \%$ probiotic ( $P$. pentosaceus and $L$. salivarius) and $0.5 \%$ G. lucidum (synbiotic) in broiler diet during 7-21 $\mathrm{d}$ old (each seven days interval) can improve broiler performance indicated by improvement of body weight gain, feed efficiency, and performance index. Broiler immunity against Newcastle diseases virus is improved and lesion of liver and intestine organ is minimized by supplementation of synbiotic.

\section{ACKNOWLEDGMENT}

The authors would like to express our gratefulness to LIPI-DIKTI Synergy Project on supporting fund research and Dr. Yantyati Widyastuti and Team (Research Center for Biotechnology LIPI) for assisting in freezedrying of lactic acid bacteria.

\section{REFERENCES}

Alavi, S. A. N., A. Zakeri, B. Kamrani, \& Y. Pourakbari. 2012. Effect of prebiotics, probiotics, acidfire, growth promoter antibiotics and synbiotic on humural immunity of broiler chickens. Global Veterinaria 8: 612-617.

An, B. K., B. L. Cho, S. J. You, H. D. Paik, H. I. Chang, S. W. Kim, C. W. Yun, \& C. W. Kang. 2008. Growth performance and antibody response of broiler chicks fed yeast derived $\beta$-glucan and single-strain probiotics. Asian-Aust. J. Anim. Sci. 21:1027-1032.

Ashayerizadeh, A., N. Dabiri, O. Ashayerizadeh, K. H. Mirzadeh, H. Roshanfekr, \& M. Mamooee. 2009. Effect of antibiotic, probiotic, and prebiotic as growth promotors, on growth performance, carcass characteristics and hematological indices of broiler chickens. Pakistan J. Biol. Sci. 12: 52-57. http://dx.doi.org/10.3923/pjbs.2009.52.57 
Ashayerizadeh, A., N. Dabiri, K. H. Mirzadeh, \& M. R. Ghorbani. 2011. Effects of dietary inclusion of several biological feed additives on growth response of broiler chickens. J. Cell. Anim. Biol. 5: 61-65.

Astawan, M., T. Wresdiyati, I. I. Arief, \& E. Suhesti. 2011. Gambaran hematologi tikus putih (Rattus norvegicus) yang diinfeksi Escherichia coli enteropatogenik dan diberikan probiotik. Med. Pet. 34: 7-13. http://dx.doi.org/10.5398/ medpet.2011.34.1.7

Awad, W. A., K. Ghareeb, S. Abdel-Raheem, \& J. Bühm. 2009. Effects of dietary inclusion of probiotic and synbiotic on growth performance, organ weights, and intestinal histomorphology of broiler chickens. Poult. Sci. 88: 49-55. http:// dx.doi.org/10.3382/ps.2008-00244

Casewell, M., C. Friis, E. Marco, P. McMullin, \& I. Phillips. 2003. The European ban on growth-promoting antibiotics and emerging consequences for human and animal health. J. Antimicrob. Chemother. 2: 159-161. http://dx.doi. org/10.1093/jac/dkg313

Gaggìa, F., P. Mattarelli, \& B. Biavati. 2010. Probiotics and prebiotics in animal feeding for safe food production. Int. J. Food Microbiol. 141:S15-S28. http://dx.doi.org/10.1016/j.ijfoodmicro.2010.02.031

Gamble, M. 2008. The hematoxylins and eosin. In: Theory and Practice of Histological Techniques. 6th Ed. Bancroft, J. D. and M. Gamble (Ed.). Churchill Livingstone, London. pp. 121-134.

Gomez, K. A. \& A. A. Gomez. 2007. Procedure of Statistics for Agricultural Research. $2^{\text {nd }}$ Edition (Indonesian Translation). University of Indonesia - Press, Jakarta.

Hume, M. E. 2011. Historic perspective: prebiotics, probiotics, and other alternatives to antibiotics. Poult. Sci. 90: 26632669. http://dx.doi.org/10.3382/ps.2010-01030

Jung, S. J., R. Houde, B. Baurhoo, X. Zhao, \& B. H. Lee. 2008. Effects of galacto-oligosaccharides and a Bifidobacteria lactis-based probiotic strain on the growth performance and fecal microflora of broiler chickens. Poult. Sci. 87:16941699. http://dx.doi.org/10.3382/ps.2007-00489.

Kalorey, D. R., N. V. Kurkure, J. S. Ramgaonkar, P. S. Sakhare, S. Warke, \& N. K. Nigot. 2005. Effect of polyherbal feed supplement "growell" during induced aflatoxicosis, ochratoxicosis and combined mycotoxicoses in broilers. AsianAust. J. Anim. Sci. 18 (3): 375-383.

Khaksefidi, A. \& S. H. Rahimi. 2005. Effect of probiotic inclusion in the diet of broiler chickens on performance, feed efficiency and carcass quality. Asian-Aust. J. Anim. Sci. 18: 1153-1156.

Lee, S. H., H. S. Lillehoj, Y. H. Hong, S. I. Jang, E. P. Lillehoj, C. Ionescu, L. Mazuranok, \& Bravo. 2010. In vitro effects of plant and mushroom extracts on immunological function of chicken lymphocytes and macrophages. British Poult. Sci. 51: 213-221. http://dx.doi.org/10.1080/00071661003745 844

Lin, Z. B. 2005. Cellular and molecular mechanisms of immunomodulation by Ganoderma lucidum. J. Pharmacol. Sci. 99: 144-153. http://dx.doi.org/10.1254/jphs.CRJ05008X

Mehdi, A. \& G. Hasan. 2012. Immune response of broiler chicks fed yeast derived mannan oligosaccharides and humate against Newcastle disease. World Appl. Sci. J. 18: 779-785.

Misra, A. K., A. S. Mishra, M. K. Tripath, R. Prasad, S. Vaithiyanathan, \& R. C. Jakhmol. 2007. Optimization of solid state fermentation of mustard (Brassica campestris) straw for production of animal feed by white rot fungi (Ganoderma lucidum). Asian-Aust. J. Anim. Sci. 20: 208-213.

Mountzouris, K. C., P. Tsirtsikos, E. Kalamara E, S. Nitsch, G. Schatzmayr, \& K. Fegeros. 2007. Evaluation of the efficacy of a probiotic containing Lactobacillus, Bifidobacterium, Enterococcus, and Pediococcus strains in promoting broiler performance and modulating cecal microflora composition and metabolic activities. Poult. Sci. 86:309-317.

Ogbe, A. O., L. O. Mgbojikwe, A. A. Owoade, S. E. Atawodi, \& P. A. Abdu. 2008. The effect of a wild mushroom (Ganoderma lucidum) supplementation of feed on the immune reponse of pullet chickens to infectious bursal disease vaccine. Elect. J. Environ. Agric. Food Chem. 7: 2844-2855.

Quereshi, S., A. K. Pandey, \& S. S. Sandhu. 2010. Evaluation of antibacterial activity of different Ganoderma lucidum extracts. People's J. Sci. Res. 3: 9-14.

Rezaeianzadeh, G., H. Dadras, A. Safar. M. Ali, \& M. H. Nazemshirazi. 2011. Serological and molecular study of Newcastle disease virus circulating in village chickens of Fars province, Iran. J. Vet. Med. Anim. Health. 3: 105-111.

Sekhon, B. S. \& S. Jairath. 2010. Prebiotics, probiotics and synbiotics: an overview. J. Pharm. Educ. Res. 1: 13-36.

Sofyan, A., H. Julendra, E. Damayanti, B. Sutrisno, \& M. H. Wibowo. 2010. Performance and histopathology of broiler chicken infected by Salmonella pullorum and fed feed additive containing earthworm meal (Lumbricus rubellus). Med. Pet. 33: 31-35.

Timmerman, H. M., A. Veldman, E. van den Elsen, F. M. Rombouts, \& A. C. Beynen. 2006. Mortality and growth performance of broilers given drinking water supplemented with chicken-specific probiotics. Poult. Sci. 85:1383-1388.

Yu, B., J. R. Liu, M. Y. Chiou, Y. R. Hsu, \& P. W. S. Chiou. 2007. The effects of probiotic Lactobacillus reuteri Pg4 Strain on intestinal characteristics and performance in broilers. Asian-Aust. J. Anim. Sci. 20: 1243-1251. 